\title{
Review of the Methods for the Evaluation of the Investment in the Offshore Centers
}

\author{
Vaidas Gaidelys
}

Kaunas University of Technology

K. Donelaicio st. 73, LT-44029, Kaunas, Lithuania

E-mail.vaidas.gaidelys@ktu.lt

cross $^{\text {ref }}$ http://dx.doi.org/10.5755/j01.ee.27.5.15373

Most of the authors emphasize the changes in the business environment, which take place after the periods of the crises have passed. The efforts, which are made by various countries (especially the countries of the EU) in order to fight against tax avoidance or aggressive schemas of planning, are accentuated. The international business often uses such instrument as offshore companies for this purpose. Since the performance of the companies, which belong to this category, is treated as breaking the law, they are perceived as illegal automatically. In juridical sense it would be difficult to qualify all the companies which are registered in offshore centers as illegal ones because in this case the companies which are registered in more than fifty offshore centers would be regarded as illegal and any business and financial transactions with these companies are against the law.

Another aspect is as follows: in the taxing schemes at the international level the companies, which perform in such centers, help to reduce corporation tax, which makes up 15\% in Lithuania. Therefore, if the companies are taxed according to the tariff which is twice as more as potential profit, the withdrawal of the capital from the country can be the only result. Also the fact that the neighbouring countries do not take analogous measures should be taken into account.

Keywords: Offshore Centre, Offshore Companies, Investments in Offshore Centre.

\section{Introduction}

The popularity of offshore centers and the extent of their use in international markets have taken on a special topicality in modern economy. On the one hand, offshore centers are used as an instrument in the process of optimizing taxes at the international level and in competition as well. On the other hand, because of such companies, the countries where high taxes are used lose billons of euros which could be made from taxation, and have more trouble in satisfying social needs. Such international schemes of taxing have become a serious challenge for the countries which use high taxes. Some of them try to isolate their taxing systems while others forbid the companies, which perform in their territories, to sign business contracts with the companies, which are registered in offshore centers. However, being isolated such countries might increase the risks of the escape of the capital from the country and, consequently, become less competitive compared with other countries. For example, such a new member country of the EU as Lithuania, aiming at more effective taxation is at risk of a future economic depression and, as a result, might sink into more serious crisis. While performing in the Eastern markets, where operations using offshore centers have already become traditional form of work, such countries do not take into account the fact that in the Eastern markets business representatives prefer involving the companies, which are registered in offshore centers. Then the countries, which use high taxes, not only lose the chances of performing in such markets but also unilaterally punish the companies which are registered in the countries where higher taxes are used.
However, the harmful effect of the offshore centers on tax collection in the countries where higher taxes are used is obvious. So, it seems to be purposeful to study the methods which are applied to assess the extent of investment in the offshore centers.

The aim of the article is to review the methods for the evaluation of the investment in the offshore centers.

The object of the article is the methods of investments in offshore centers.

The methods of the article are empirical analysis, the analysis of scientific literature, statistical method, comparative analysis, Offshore Financial Centre investment econometric model.

Only a statistical method, comparative analysis and Offshore Financial Centre investment econometric model were used to perform the research.

The methods are used in the article was analysed on the basis of the IMF and OECD data. An empiric analysis, the analysis of scientific literature were used in the article. The analysis also includes the overview of a Offshore Financial Centre investment econometric model.

\section{Performance of Offshore Companies Worldwide}

While analyzing the issues related to the performance of offshore companies some of the authors assess the situations, which can take place while the offshore companies operate. Though, the harmful effect on the taxation systems in the countries, which is caused by reducing taxes through offshore companies, is not usually assessed. The situation causes certain problems for both the sides (Гаркуша, 2001). 
The extents of the performance of offshore companies, their legitimacy as well as the problems, which take place due to legalization of illegal profits (so called moneylaundering) are analyzed by various authors. However, the problems, which are connected with confidentiality of the performance of offshore companies, have existed up till now. The problems, which are caused by the lack of control of offshore centers, were considered during the international conference in 2001. One of the authors maintained in the report that in order to control the performance of offshore centers relative juridical acts, which could regulate the performance of offshore centers, should be passed (Komisar, 2001). That is why every time separate organizations and countries deliver the certain initiative in pressing of the offshore centers. The European Union showed such initiative towards Luxembourg in 1973. The initiative concerned the holdings, which performed in Luxembourg and were intensively demanded in the market of offshore companies. Though, having examined this problem especially carefully the European Commission had found that it was necessary to analyze not only the performance of Luxembourg but also Jersey, the Isle of Man, Guernsey and other countries. The Commission also had drawn the conclusion that the restriction on the performance of the countries, where easy taxes are used, would stimulate leaking the capital out of the partnership (Apel et al., 2002). Here one more problem, which is connected with the escape of the capital from the countries of the European Union, can be met. The problem is not caused only by the performance of offshore companies, but it is the global phenomenon, which takes place due to the escape of the capital from the old Europe in general. It also includes the relocation of production from European countries to Asia and, first of all to China, from where expensive goods are imported to the countries of the EU. Therefore, offshore companies become one of the instruments, which are used in the battle of rivals. According to the other authors, while performing in such business surroundings as Eastern Europe it is very difficult to avoid the models of organization of business without applying of offshore companies (Snieska, 2005).

It is remarkable that despite the fight, which has been kept on by international organizations against the harmful effect on the taxation in the countries, which is caused by offshore companies; on the other side some of the countries establish offshore centers in their territories (Snieska, 2006).

There are the problems, which are connected with the difference between the sizes of the taxes, which are designated in the EU, and the taxes, which are paid in offshore centers or sometimes are not paid at all. The problem related to taxes in the EU was also studied by $\mathrm{C}$. Radaelli (2009), who at the same time analyzed the taxation systems, which were used in offshore centers. The other authors maintain that the countries of Western Europe have already had the instruments to safeguard their interests. The obligatory inspection of the contracts, which were signed by the country's residents (in the most of European countries) with the companies registered in offshore centers, which is carried out by the tax institutions, is considered to be one of such instruments. If such contracts are not isolated such resident is inspected especially carefully. Besides, in some countries all the remittances, which are made to offshore companies, are taxed extra (Apel et al., 2002). As it was mentioned above such actions can still cause negative results for the economy of the EU, among which the escape of the capital from the countries takes the first place.

Despite the fact that the services, which are provided by offshore centers, can be used by various criminal structures as well as terrorist organizations, according to some authors, the European countries have achieved good results in controlling of the use of the services, which are provided by offshore structures, by the country's residents. (Апель et al., 2002).

It is remarkable that the international corporations, which are capable of successful redirection of the business and optimization of the taxes, which are paid by them, invoke the companies, which are registered in financial offshore centers, more often (figure 1).

Having performed the empirical analysis of scientific studies it was found that:

Table 1

Investments in Offshore Financial Centers

\begin{tabular}{|l|c|}
\hline Companies & $\begin{array}{c}\text { Offshore financial centers } \\
\text { (bln.USD) }\end{array}$ \\
\hline Apple & 181 \\
\hline GE & 119 \\
\hline Microsoft & 108 \\
\hline Pfizer & 74 \\
\hline IBM & 61 \\
\hline Merck & 53 \\
\hline Johnson \& Johnson & 52 \\
\hline Cisco & 51 \\
\hline ExonMobil & 47 \\
\hline Google & 45 \\
\hline
\end{tabular}

According to V. Snieska, in a broad sense the surroundings is everything that is around some object. It is difficult to range over business surroundings, because it can be studied endlessly due to new information, which comes continually. The task can become easier due to the abridged concept of business surroundings, which is as follows: the business surroundings is something that is around the enterprise and helps to achieve the business goals, which are set by the company (Snieska, 2005). The rules, which affect the business surroundings, are available in offshore business as well, because despite the fact that offshore business is regarded as a specific part of business it is influenced by the factors, which form business surroundings, as well as other spheres of business are.

The other authors maintain that competition has become one of the main movers of our economy. Due to developing industry and advanced technologies the competition has become stronger and at the same time new, more complicated forms of competition come. The authors define competition as such situation in the market, when there are quite a lot of customers and sellers, the participants are allowed to be free in their choice to enter the market and exit at any time, the information about the prices, which are offered by other fabricants, is available and approachable. Recently the concept of "hypercompetition' has become a popular idea in the theory and practice of economics. It is defined as such situation, when the companies are mostly influenced totally by the competitive factors, which had been isolated one from another before, which leads to multidimensional, dynamic, aggressive competition (Snieska, 
Sliburyte, 1999). Use of offshore companies in business operations partly helps to fight against rivals successfully, though offshore centers are usually established for other purposes the topic is considered in the present work) (Dumciuviene, 2005).

At present the offshore center, which was established in October, 1992 in Delaware (the USA), is one of the most popular centers in Lithuania (Wyoming (the USA) is considered to be the pioneer in founding the companies of LLC type, because the first company of this type was founded on the $4^{\text {th }}$ of March, 1997 in this state). The companies of LLC (Limited Liability Companies) type, which started their performance in the offshore center in Delaware, were accepted as novelty that time.

The companies of such structure came is related to the companies, which performed in Germany and some of the countries of South America. For example, the companies of GmbH (Gesselschaft mit beschranker Haftung) type, which have been performing in Germany since 1892, have the similar structure. The companies of such structure also perform in France (SARL), Switzerland, Italy (SRL), Belgium, Turkey, Mexico, Argentina, Chile and Panama (Dovidka, 2002).

It is remarkable that in former Soviet countries free economical zones were founded in the last decade of the XX century though they failed to become popular, because they were not motivated to work (Rustamova, 2001). The offshore center, which performs in Ingushetia (Russia) as one of the most famous zones, was founded in December, 1995 and validated on the $15^{\text {th }}$ of January, 1996 (Guceriyev, 1996). According to officials approach such zones were supposed to stimulate the performance of the local companies and create corporations.

Having analyzed the payments of the Central Bank of Russia it was noticed that in 1999 the extent of leakage of the capital out of Russia decreased from 25,5 billion American dollars to 18,8 billion American dollars (Apel, 2000). On the $1^{\text {st }}$ of January, 2002 the new order of paying taxes, which, according to specialists, should have paralyzed the performance of offshore centers in Russia totally, was carried (Виркуненб, 2001).

Meanwhile the Islamic State began to play conversely and established absolutely new offshore center Anjouan in the territory of the Comoros (Mugge, 2014). This country, which declared its independence at the end of 1990, passed the relative juridical acts, which confirmed its status as offshore center.

Aiming at the more thorough analysis of the reasons why offshore centers came, it seems to be purposeful to ventilate the economical situations, which influenced the process of creating of offshore centers and their development (Мельник, 2000).

While assessing the performance of offshore centers the American judge Leernd Handa said, "Justice admits one more time that to develop the business and pay minimum taxes does not mean doing something wrong. Such behavior is typical for everyone, for the poor and the rich as well, and they are right. Persons do not have to pay more than they are obliged by law, because the tax is obligatory pay. To require more with reference to this moral stimulus means to pretend" (Восточный базар, 2001).
In our opinion, nowadays the number of offshore centers has increased a lot and their residents try to use the services, which are provided by these centers. It is also remarkable that due to especially wide range of the services, which are offered by offshore centers, there are more reasons, which encourage people to use these services. (Gaidelys, 2003).

Increment of the capital is essentially one of the main purposes of establishing offshore centers. It must overpass the return in percents comparing them with the transference of finances to any of financial instruments in the country, where the residents act as founders of an offshore company (Rixen, 2013).

The other authors maintain that one of the most important problems to solve for management is the link between the strategy and resources, where the main tings to deal with are as follows (Dagiliene, 2014):

1. Does the company possess enough resources to realize their strategy?

2. Is it possible to get or form additional sources during a short period of time and at a reasonable price if it is necessary?

3. Do any new strategic initiatives, which are based on unemployed resources, exist to discuss them?

The businessmen, who apply the services provided by offshore business, meet the similar problems. Though they usually use offshore companies only as formal mediators (Picard, 2011).

According to the information, which is presented by the most of the authors, to start up an offshore company it is necessary to choose an offshore center (considering the specialization) according to the request of the founder of the potential offshore company. Some of jurisdictions are traditionally considered to be the jurisdictions of the holding and the others are recommended to the firms of international trade, banks, trusts, insurance companies (for example, the captive insurance, i.e. the insurance inside the company or reinsurance firms) (Stungys et al., 2001). In the opinion of the other authors, before choosing an offshore center it is necessary to know that one of the main disadvantages of offshore centers is connected with the situation when the owners of the firms, who exploit tax concessions, are not allowed by law to live and to do their duties in the territory of the most of the offshore centers. (Masciandaro, 2008). Some of the authors think that the more important question of the day is related to the situation, when various persons take the capital out of the country for the purpose of moving abroad to dwell. Their intentions of changing the dwellingplace are usually connected with such places as the Bahamas, Cyprus or the Seychelles (Stungys et al., 2001). Moreover, it is maintained that "tax concessions are available for the foreigners, who belongs to the offshore companies, which are not controlled from Cyprus" (Stungys et all., 2001). Nevertheless, the offshore business is considered to be grounded on the potentials, which are ensured by offshore centers (Rixen, 2013).

It has been noticed that the two following ways of the potential use of offshore companies have been emphasized recently: optimization of the performance of juridical persons and individual goals of physical persons (the group of the persons). In the first case the offshore business partly helps to reduce taxes and enables to diminish the cost price 
of the production, which provides the stronger competitive abilities of the production (Table 2). In another case the offshore business enables the certain person or the group of the persons to deal with the particular financial situation. However, in the particular case the above-mentioned goals might agree or disagree.

Table 2

The Concessions, which are Provided in Offshore Centers

\begin{tabular}{|l|l|}
\hline NR. & \multicolumn{1}{|c|}{ The Description Of The Provided Concessions } \\
\hline $\mathbf{1 .}$ & $\begin{array}{l}\text { The offshore firms, which are established, are free of charge or } \\
\text { are charged only a small registration tax (100-150 American } \\
\text { dollars). }\end{array}$ \\
\hline $\mathbf{2 .}$ & $\begin{array}{l}\text { The system of registration of the firm is simple and cheap. In } \\
\text { order to register the firm it is necessary to put its name, the date } \\
\text { of the registration and the registration number only. The } \\
\text { procedure of the registration is usually committed to the } \\
\text { engaged company, which specializes in secretarial services and } \\
\text { later usually becomes the administrator of the firm, because the } \\
\text { owner of the firm does not have to participate in the procedure. } \\
\text { The services provided by the secretarial company are paid in } \\
\text { advance for the following year by the owner, who also pays the } \\
\text { registration charge. The expenditures on establishment and } \\
\text { administering of the firm make on an average 2-3 thousand } \\
\text { American dollars during the first year of the performance. }\end{array}$ \\
\hline 3. & $\begin{array}{l}\text { The companies, which are established by non-residents, the } \\
\text { financial liability is simplified, i.e. bookkeeping is not required, } \\
\text { audit and other regulations are not necessary. Such situation is } \\
\text { convenient for the businessmen, who tend not to publicize their } \\
\text { performance. }\end{array}$ \\
\hline 4. & $\begin{array}{l}\text { After the companies have been established they are allowed to } \\
\text { open bank accounts in the most of the countries without } \\
\text { restrictions, to perform payment operations in various } \\
\text { currencies, they also can bring their assets in and away as a } \\
\text { foreign capital at any time (Buskeviciute \& Pukeliene, 1998). }\end{array}$ \\
\hline
\end{tabular}

Having analyzed some of the peculiarities of offshore centers it seems to be purposefully to present the actions, which are necessary to found an offshore company, as well as the general scheme how to open it:

1. To arrange the form of the legal performance of the offshore company (some of the authors recommend to send the request by e-mail, which is created in a foreign server, or by fax with the address, where the papers of the offshore company must be sent; the telephone or the fax number should not be disclosed as well as the exact address (Arestarchovas, Arsenevas, 2002);

2. To examine the taxing status of the offshore company, to choose the optimal plan of the actions and payments. (Dovidka, 2002);

3. To organize the process of the registration of the offshore company (according to the authors, the companies, which register offshore companies, perform through the designated consultant, with whom the potential owners of the company contact constantly) (Arestarchovas ir Arsenevas, 2002);

4. To sign the contract with the bank and to open the bank account;

5. To obtain a credit card;

6. To team up the staff with the minimum number of the employees to perform the initial operation;

7. To obtain blanks, visiting cards, organizational equipment.

As we know the firms, which register offshore companies, offer standard set of documents, which includes the following papers:
1. The memorandum and the articles of the association (factual statutes);

2. The registration certificate;

3. The certificate of the juridical address;

4. The certificate of the founders;

5. The resolution of the stock holders;

6. The resolution of the directors;

7. The certificates of the shares;

8. The resignations, which are signed by the directors in advance;

9. The papers about the disposal of the shares, which are signed in advance;

10. The stamp of the offshore company.

Some of the authors maintain that the firms, which form or realize their profit independently, would act purposefully if they transferred it in the form of dividends (as they are not usually taxed) or in royalties to some country with the tolerant system of taxes, because in such countries the agreements on double tax avoidance are usually signed. Aiming at transferring finances to one of offshore centers it is advisable to do it in the form of internal credits and interests for them having signed internal agreements between the firms (Masciandaro, 2008).

All the countries and jurisdictions of this short list are well-established Offshore Financial Centers that participate in the International Monetary Fund Offshore Financial Centers program, except Latvia and Uruguay. Latvia is known to host numerous offshore banks and companies serving mainly nonresident CIS19 clients, with offshore investment coming from Eastern Europe and Russia. Indeed, more than half of bank total deposits in Latvia are of nonresident origin (Olatunde, 2012). As for Uruguay, its Offshore Financial Centers status is demonstrated by the operations of some 12 offshore banks and about half a dozen offshore mutual fund companies. Uruguay is already under consideration for participation in the International Monetary Fund Offshore Financial Centers program (Barth, 2001).

\section{Comparison of Methodology}

While carrying out the researches on the taxes, which were paid by offshore companies, or on the harmful effect to the budgets of the countries, where higher taxes are used, the topics, which are related to the problem of identification of the performance of offshore companies, are always met. It is caused by the circumstances that as a rule such companies perform confidentially aiming not to disclose the information about the real owners of the company and using bearer shareholding. Consequently, identification of the extents of the performance of offshore companies through banks accounts can be used as one of possible ways though the problems related to the bank confidence take place, because commercial banks in Western countries put all possible efforts in order to keep their commercial information secret as well as the information about their clients (Tint, 2010).

With regard to such business surroundings some of the authors try to suggest new methods of the assessment of the performance of offshore companies.

The other problem is related to the proper assessment of the investments from offshore financial centers in the economies of the countries, where the higher taxes are used. 
The main problems, which are connected with the investments from offshore financial centers, are as follows:

- The identification of the origin of the capital;

- Distorting of the real amount of the direct investments from abroad;

- The potential stimulation of the grey economy and the expansion of its part in the national economy.

Regarding the identification of the origin of the capital the risks of attracting the illegal finances and thus being involved into the schemes of money-laundering or tax avasion take place (Taujanskaite, 2016).

Regarding distorting of the real amount of the direcr investments from abroad there is the risks of being involved into the schemes of refunding, i.e. diminishing of the funds, which came due to the use of aggressive modes of tax planning, and especially due to decreasing of the corporation tax (Antoine, 2001).

Regarding the potential stimulation of the grey economy and the expansion of its part in the national economy the risks of attracting the funds, which came due to use of opaque methods, thus contributing to expansion of the part of the grey economy in the national economy take place (Arter, 2000).

Aiming at the maximum protection of national economies from the investments, which are risky in their origin, it is purposeful to assess as many factors as it is possible, so it is necessary to select the most suitable methods of the assessment of the investments in the economies of the countries, where the higher taxes are used, which could assess the larger number of components (Vlcek, 2006).

The other authors maintain that the various researches show that the economic policy of the countries, which stimulates the flows of the capital from abroad, is not always correct: in some cases the direct investments from abroad have the negative influence on the domestic economy, and sometimes the positive effect may turn to the negative one. So, the attitude towards the assessment of the importance of the direct investments from abroad must be motivated (Krusinskas, 2005).

The other authors maintain that when the direct investments from abroad come to the economy of the developing country, the changes in the economical development of the country, which accept the investments, take place. At the same time the economical conditions for the potential flows of the foreign capital change as well. During the process of the development of the economy the effects of the coming of the direct investments from abroad also vary. For example, the influence of the direct investments from abroad on the economical development in the developed country is different than the influence of the foreign capital on the economy of the country, which is at the earlier stage of the development.

In averagely 3-5 years after the direct investments from abroad come to the country, which accept them, the intensity of the influence of the investments and even the course may change.

The logic and the sequence of the research, or in other words, the model, could be applied to the assessment of the influence of the direct investments from abroad, which takes place not only in Lithuania, Latvia, Estonia, but also in the other countries of the EU, especially at the stage of economical reformation.

Gonzalez and Schipke (2011) identified some ways, which could be applied by offshore financial centers in order to compete with traditional financial centers. First of all, they differ, because offshore centers usually use low or zero levels of taxation. Due to such condition most of the companies and investors avoid the high level of taxation using offshore centers. The businessmen, which use such an aggressive method of tax planning, can avoid declaring of incomes easily or to conceal them in some other way in offshore financial centers using the daughter enterprises, which registered their seats in offshore financial centers. For example, the international business company registers the seat of the daughter enterprise in one of offshore financial centers and later buys non-existent real services from this enterprise at the price, which is higher than the market prices. All the incomes, which are made by the daughter enterprise, are not taxed or the tax is reduced. Investors also can use offshore centers in the financial structure of the parent company; thus the investors avoid drastic methods of administering and regulating of taxes and, as a result, avoid stricter control in the countries, which use higher taxes and where the business performs really.

Some of the authors maintain that the companies, which are registered in offshore financial centers, apply the international banking services mainly in the six countries, which are considered to be politically and economically unstable ones (Gonzalez, Schipke, 2011). According to the authors the clients of the offshore centers can safeguard their money and at the same time to get state subsidies from the countries, where higher taxes are used, avoiding the control.

According authors, given these motivations, we can identify several national level characteristics that may influence the degree to which investors in a country utilize Offshore Financial Centre. As investors utilize Offshore Financial Centre to avoid taxes in their home country, some measure of home country taxation is clearly warranted (Blanco, 2009). To capture this, utilize several components of the Heritage Foundation's index of economic freedom. Fiscal Freedom is defined as a measure of the tax burden imposed by the government and is graded from 0 to 1 , with 1 representing the lowest tax burden and 0 the highest tax burden. As the benefits for using an Offshore Financial Centre are lower as fiscal freedom increases, this variable should have a negative relationship with Offshore Financial Centre investment (Dharmapala, 2009). Investment Freedom measures restrictions on the low of investment capital across markets and borders. On one hand, fewer restrictions on capital flows may increase the usage of Offshore Financial Centre by making it easier to invest there. On the other, a country with restrictions on international capital may induce investors to park their money in an Offshore Financial Centre for greater mobility (Evans, 2009). Financial Freedom measures independence from government control in financial markets. As financial freedom increases, investors have less of an incentive to utilize Offshore Financial Centre, so this should be negatively related to Offshore Financial Centre investment. To capture other aspects of economic freedom, also include the aggregate index of Economic Freedom which combines the three variables discussed above as well as indicators for 
business freedom, trade freedom, monetary freedom, government spending, property rights protection, freedom from corruption, and labor market freedom (Hines, 2010). Another motivation for utilizing Offshore Financial Centre is to protect investments from government appropriation in countries with weak property rights. Property Rights is also taken from the Heritage Foundation and is defined as an assessment of the ability of individuals to accumulate private property, secured by clear laws that are fully enforced by the state. The higher this number, the greater property rights are protected in a country and would expect less usage of Offshore Financial Centre (Lane, 2011). To augment this variable, it also collect data on how well corruption is controlled from the World Bank's Worldwide Governance Indicators. This variable reflects perceptions of the extent to which public power is exercised for private gain, including both petty and grand forms of corruption, as well as "capture" of the state by elites and private interests. Two other national governance variables of interest are how effective the government is in general and how well regulations are enforced. From the Worldwide Governance Indicators and collect data on regulatory quality, which rejects perceptions of the ability of the government to formulate and implement sound policies and regulations that permit and promote private sector development. It also gather data on government effectiveness, which rejects perceptions of the quality of public services, the quality of the civil service and the degree of its independence from political pressures, the quality of policy formulation and implementation, and the credibility of the government's commitment to such policies (Gonzalez, 2011).

Several other national level characteristics are of interest. Do larger economies tend to utilize Offshore Financial Centre more than smaller economies? It assess this by looking at both the total Gross Domestic Product and the population of a country. What about the average income in a country? To assess whether richer countries utilize Offshore Financial Centre more than poorer countries, It also include Gross Domestic Product per capita. Countries with greater savings rates will naturally have more capital to invest, perhaps in Offshore Financial Centre (Organization for Economic Cooperation and Development, 2009). To capture this It include a measure of the savings rate defined as national savings over Gross Domestic Product. Finally, investors in high inflation countries may be more willing to move their money out of the country, so it should utilize the annual inflation rate for that year. All of this information comes from the IMF's International Financial Statistics. It measure Offshore Financial Centre investment as the share of a country's total outward portfolio investment that goes to Offshore Financial Centre. Thus, it considering why some countries foreign investment is more heavily oriented towards Offshore Financial Centre than others. It do this by using the IMF's Coordinated Portfolio Investment Survey (International Monetary Fund, 2010). This database collects bilateral investment holdings for a large range of countries over the period 2001-2009. It aggregate outward portfolio investment positions over 63 countries for which it have complete data across the years 2001-2009. These 63countries invest in up to 243 foreign jurisdictions, of which 49 are classified as Offshore Financial Centre for which they have fairly complete data.
Other authors present a profile of the investment patterns of some of the countries in my sample. The top half of the table shows the 12 countries with the highest share of Offshore Financial Centre investment based on the IMF list of Offshore Financial Centre in 2009, while the bottom half shows the 12 countries with the lowest share of Offshore Financial Centre investment. There are no clear patterns that emerge from this table other than the fact that there is tremendous heterogeneity in Offshore Financial Centre investment shares. Russia leads the way with $65.3 \%$ of outward Russian investment going to Offshore Financial Centre (Rose, 2007). This would seem to indicate that the weak property rights and corruption in Russia are driving Offshore Financial Centre investment. However, a country like Iceland with fairly strong property rights (property rights index of 90 compared to Russia's 25) also has over $40 \%$ of foreign investment in Offshore Financial Centre. Furthermore, Kazakhstan with a very low property rights score (40) has one of the lowest Offshore Financial Centre investment shares at only $2.0 \%$. There are both rich countries and poor countries in both the top and bottom 12, large and small economies, countries with good and bad regulatory quality and government effectiveness. All of this point to the need to assess the determinants of Offshore Financial Centre investment using a multivariate approach (World Bank, 2010).

It assess the determinants of Offshore Financial Centre investment shares using the following econometric model (Foad, 2012):

$$
\begin{aligned}
& \text { OFCI }_{i, t}=\beta_{0}+\beta_{1} \text { EconFree }_{i, t}+\beta_{2} \text { FiscalFree }_{i, t}+\beta_{3} \text { InvFree }_{i, t} \\
& +\beta 4 \text { FinFree }_{i, t}+\beta_{5} \text { Prop }_{i, t}+\beta_{6} \text { Corrupti }_{i, t}+\beta_{7} \text { RegQ }_{i, t} \\
& +\beta 8 \text { GovEffi }, t+\beta 9 \operatorname{lnGDP}_{i, t}+\beta 10 \operatorname{lnGDPpci,t}
\end{aligned}
$$

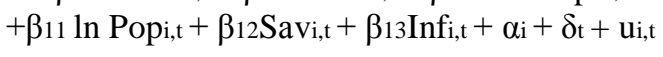

OFCI $i, t$ is the share of Offshore Financial Centre investment by country $i$ in year t. EconFree, FiscalFree, InvFree, and Fin Free represent Economic Freedom, Fiscal Freedom, Investment Freedom, and Financial Freedom. Prop is a measure of property rights protection, while Corrupt measures protection from corruption. RegQ is regulatory quality and Gove is government effectiveness. Gross Domestic Product, Gross Domestic Product per capita, and population are all logged, while the savings and inflation rates are expressed in decimal form. I also include a set of country and year fixed effects (Ledyaeva, Karhunen, Kosonen, Whalley, 2011).

According to the other authors while assessing the macroeconomical effect of foreign investments to the economies of the countries the simpler model, which is usually used to assess the bilateral trade, is possibly suggested. The model is grounded on the GDP to one separate resident, the rates of the growth of the GDP, the degree of the openness of the economy to the investments from abroad (the ratio of inward FDI stock to GDP of the host country), the interest rate, the level of inflation and natural resources. While applying this model the other auhors showed the relation between the above mentioned factors and the economies of the countries. The other authors express the opinion that the model can be expanded and include the effect of the OFC as an additional factor while assessing the direct foreign investments to the 
country. In that case there is no need to assess the factors at the level of the company, which enables to concentrate on macroecoomcal factors of the countries. So, the following formula is offered for use:

\section{OFDI $=\alpha+\beta 1$ Trade $+\beta 3 g+\beta 4$ Exrate $+\beta 6$ openness $+\beta$ $70 F C+\beta 8$ Inst $+\varepsilon$;}

OFDI is the sum of logarithm values of country outward FDI flow to a host country. It is a total of loan, equity and guarantee issued investments in foreign countries. Due to the inaccessibility of FDI data (country-wise) before the period of regression. The unit is in US\$, and it has been taken from the one of databases.

Trade measures the logarithm values of total bilateral trade. Measured in US\$, it has been taken from the one of databases. It is the sum of country exports to the host country and imports from it.

$\mathrm{G}$ is the nominal level of the GDP growth, which took place last year (during one year) in a one of the countries. The rate can be found in some other data-bases, for example, from CEIC.

Exrate is the annual exchange rate of the host country currency. It is the ratio of the quarterly average value of the host country's currency. It has been taken from the one of database and has no unit.

Openness is assessed in order to measure the openness of the national trade in the market of the country, which is researched. To figure it out it is necessary to divide the total internal trade of the host country by the GDP of the host country. The ratio in this equation was used as a dummy variable: if the ratio is more than $100 \%$, then the variable assumes the value of 1 , and it assumes the value of 0 if this ratio is less than $100 \%$. In this case it is recommended to apply CEIC data-bases.

OFC is a dummy variable which is 1 , if the host country is an IMF-certified offshore financial centre and 0 otherwise.

Inst is a weighted index that measures the institutional quality of the host country based on three indicators taken from the World Bank or other database: Rule of law, Government effectiveness and Control of corruption.

\section{The Investments in Offshore Centers}

The other authors emphasized the main offshore centers, where the registered companies are treated as offshore ones. It is necessary to remark that the identification of offshore centers, which is presented by the International (table 3).
Table 3

List of offshore centers according to IMF and OECD (IMF, OECD):

\begin{tabular}{|c|c|c|c|c|c|}
\hline $\begin{array}{l}\text { Country } \\
\text { Name }\end{array}$ & 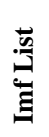 & 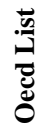 & $\begin{array}{l}\text { Country } \\
\text { Name }\end{array}$ & 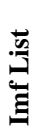 & 苞 \\
\hline Andorra & + & + & Anguilla & + & + \\
\hline Aruba & + & + & Austria & - & + \\
\hline Bahamas & + & + & Bahrain & + & + \\
\hline Barbados & + & + & Belgium & - & + \\
\hline Belize & + & + & Bermuda & - & + \\
\hline $\begin{array}{l}\text { British Virgin } \\
\text { Island }\end{array}$ & + & + & Brunei & + & + \\
\hline $\begin{array}{l}\text { Cayman } \\
\text { Island }\end{array}$ & + & + & Cook Island & + & + \\
\hline Costa Rica & + & + & Curacao & + & + \\
\hline Cyprus & + & + & Djibouti & + & + \\
\hline Dominica & + & + & $\begin{array}{l}\text { French } \\
\text { Polynesia }\end{array}$ & + & + \\
\hline Gibraltar & + & + & Grenada & + & + \\
\hline Guatemala & - & + & Guernsey & + & + \\
\hline Hong Kong & + & + & Hungary & - & + \\
\hline Ireland & + & + & Isle of Man & + & + \\
\hline Jersey & + & + & Kiribati & - & + \\
\hline Latvia & - & + & Lebanon & + & + \\
\hline Liberia & + & + & Liechtenstein & + & + \\
\hline Luxembourg & + & + & Macao & + & + \\
\hline Maldives & - & + & Malta & + & + \\
\hline $\begin{array}{l}\text { Marshall } \\
\text { Island }\end{array}$ & + & + & Mauritius & + & + \\
\hline Monaco & + & + & Montserrat & + & + \\
\hline Nauru & + & + & $\begin{array}{l}\text { Netherlands } \\
\text { Antilles }\end{array}$ & + & + \\
\hline New Zealand & + & + & Niue & + & + \\
\hline Panama & + & + & Philippines & + & + \\
\hline $\begin{array}{l}\text { Pitcairn } \\
\text { Island }\end{array}$ & + & + & Samoa & + & + \\
\hline San Marino & + & + & Seychelles & + & + \\
\hline Singapore & + & + & Sint Maarten & + & + \\
\hline $\begin{array}{l}\text { St. Kitts and } \\
\text { Nevis }\end{array}$ & + & + & St. Lucia & + & + \\
\hline St. Vincent & + & + & Switzerland & + & + \\
\hline $\begin{array}{l}\text { Turks and } \\
\text { Caicos }\end{array}$ & + & + & UAE & + & + \\
\hline Uruguay & + & + & $\begin{array}{ll}\text { US } & \text { Virgin } \\
\text { Island } & \\
\end{array}$ & - & + \\
\hline Vanuatu & + & + & & & \\
\hline
\end{tabular}

The IMF list is based on countries in which a significant amount of fiscal activity involves offshore parties on both sides of the transaction. The OECD list is based on countries classified as "offshore companies".

In our opinion, the general investment in the companies, which are registered in offshore centers, usually come from the countries, where the higher taxes are used. Such countries are often autocratic and the business climate there is quite risky, though the business is profitable and the business relations with the companies, which are registered in offshore centers, are tolerated by the state government and administrative institutions. On the contrary, the 
investments in the offshore centers of other countries are not treated by business as priority in the developed countries, which established offshore centers in their territories.

\section{Conclusions}

- In the worldwide tax schemas due to the companies, which perform in such centers, the corporation tax, which makes $15 \%$ in Lithuania, is usually reduced, so, if such companies are taxed according to the tariff, which is twice as more as the potential profit, the withdrawal of the capital from the country can be the only result; also the fact that the neighbor countries do not take analogous measures should be taken into account.

- It is difficult to deny the fact that the use of offshore companies in international economical and financial operations influences taxation systems in the countries negatively;

- Some other tendencies dominate in the Eastern market. They tell that aiming at performing in the markets of Russia, Belarus, Ukraine and other eastern countries the businessmen of the eastern markets are interested in the use of the companies, which are registered in offshore centers, trying to avoid the model of the currencies control, which is used in their country (for example, Russian men of business). Due to the lack of comprehension some of the countries of the EU try to outlaw the internal companies, which transact with the companies, which are registered in offshore centers;

- Some of the largest companies in the USA act as the active investors of the companies, which are registered in offshore centers;

- Nowadays the return, which is made using offshore centers, has increased significantly and a lot and their residents try to use the services, which are provided by these centers. It is also markable that due to especially wide range of the services, which are offered by offshore centers, there are more reasons, which encourage people to use these services;

- Russia leads the way with $65.3 \%$ of outward Russian investment going to Offshore Financial Centre.
This would seem to indicate that the weak property rights and corruption in Russia are driving Offshore Financial Centre investment. However, a country like Iceland with fairly strong property rights (property rights index of 90 compared to Russia's 25) also has over $40 \%$ of foreign investment in Offshore Financial Centre;

- Offshore Investment Centre Financial Econometrics model application indicate that the weak property rights and corruption in Russia and other cotries are driving Offshore Financial Centre investment.

- The Offshore Financial Centre investment econometric model is grounded on the GDP to one separate resident, the rates of the growth of the GDP, the degree of the openness of the economy to the investments from abroad (the ratio of inward FDI stock to GDP of the host country), the interest rate, the level of inflation and natural resources.

- Although presentation on an asset/liability basis is appropriate for macroeconomic analysis (i.e. the impact on the balance of payments), the directional basis is more useful in formulating investment policies because they capture the source or destination countries of direct investment and access to specific markets by direct investors;

- This article supports the reality that OFCs remain attractive destinations for FDI, due to their tax- and legalprotection advantages, despite significant developments in trade, institutions or on the growth front. As long as there are differences in national tax rates, regulatory standards and confidentiality laws, OFCs will exist;

- The second econometric model of the assessment of the investments from offshore financial centers, which is offered, contains the assessments of some more factors, such as EconFree, FiscalFree, InvFree, and Fin Free represent Economic Freedom, Fiscal Freedom, Investment Freedom, and Financial Freedom at al. So, in our opinion, the last mentioned econometric model reflects the influence of the investments from offshore financial centers more thoroughly. Whereas, using the first model of the assessment of the investments from offshore financial centers mostly the general macroeconomical indexes, which do not reflect so precisely the influence of the investments from offshore financial centers on the economies of the countries, where the higher taxes are used.

\section{References}

Antoine, R. (2001). The Offshore Financial Services Sector: Legal Policy Issues on the Path to Development: A Legal Defence. Journal of Eastern Caribbean Studies 26(4), 1-27.

Arter, D. (2000). Small State Influence Within the EU: The Case of Finland's 'Northern Dimension Initiative. Journal of Common Market Studies 38(5), 677-697.

Апель, А., Гунько, В., Соколов, И. (2002). Обналичивание и оффшорный бизнес в схемах. Питер. Закон и практика, p. 80-86.

Barth, M. H., \& Blanco, M. (2001). US Regulatory and Tax Considerations for Offshore Funds. The Journal of International Business and Law. 1(1), [2002], Art. 1.

Blanco, L., \& Rogers, C. (2009) Are Tax Havens Good Neighbors? An LD Perspective. Available at SSRN: http://ssrn.com/abstract=1432630. 
Dagiliene, L. Leitoniene, S., Grencikova, A. (2014). Increasing Business Transparency by Corporate Social Reporting: Development and Problems in Lithuania. Inzinerine Ekonomika-Engineering Economics. 25(1), 54-61. https://doi.org/10.5755/j01.ee.25.1.2356

Dharmapala, D., \& Hines, J.R. Jr. (2009) Which Countries Become Tax Havens? Journal of Public Economics, 93(9): 1058-68.

Kung, P., \& Michel, O. (1998). Ressourcen: Expansion will uberlegt sein. BOOM. 1998. No. 3/98, Apriel/Mai-Heft, p. 4445.

Dumciuviene, D.; Meiliene, E.; Snieska, V. (2005). Konkurencingumo ir sanglaudos rysiai Europos Sajungos politikos kontekste. Kauno technologijos universitetas. Lietuvos teises universitetas. Viesoji politika ir administravimas Nr. 13.

Foad, H. (2012). The Determinants of Offshore Financial Center Investment. Department of Economics, San Diego State University. San Diego, p.1-8.

Komisar, L. (2001). After Dirty Air, Dirty Money. The Bush Administration Is Blocking Efforts To Rein In Offshore, NATIO, 2001, P. 16-21.

Krusinskas, R., \& Vasiliauskaite, A. (2005). Technology Investment Decisions to Increase Company Value. Inzinerine Ekonomika-Engineering Economics. 4(44), 7-16.

Lane, P., \& Milesi-Ferretti, G. M. (2011). Cross-Border Investment in Small International Financial Centers. International Finance, 14(2), 301-330.

Ledyaeva, S., Karhunen, P., Kosonen, R., \& Whalley, J. (2011). Round-trip investment between offshore financial centers and Russia: An empirical analysis. Aalto University School of Business, Centre for Markets in Transition.

Мельник, Д. Ю. (2000). Налоговый менеджмент. "Финансы и статистика", 2000, p. 352.

Mugge, D. (2014). Europe and the Governance of Global Finance. Oxford University Press. ISBN: 978-0-19-968396-3. https://doi.org/10.1093/acprof:oso/9780199683963.001.0001

OECD (2015). Fiscal Committee and the Action 11 Focus Group of the OECD/G20 BEPS Project for inclusion in the deliverable for Action 11 as signal indicators.

Olatunde J. O., \& Lauwo, S., (2012). The role of offshore financial centers in elite money laundering practices: evidence from Nigeria. Journal of Money Laundering Control, 15(3), 336-361. https://doi.org/10.1108/13685201211238070

International Monetary Fund (2011). International Financial Statistics. Retrieved from http://elibrary-data.imf.org.

Gaidelys, V. (2003). Ofsoriniai centrai Lietuvos įmonių tarptautiniame versle: moksline monografija. Kaunas : Technologija, 2004. 332 p. ISBN 9955095571.

Гаркуша, В. (2001). Анжуанские компании позволяют реализировать класичесткие оффшорные схемы без "налогавых репресии" со стороны властеи. Практика изпозования оффшорных компаний 1-8 часть. Восточный базар. 1998-2001.

Gonzalez, M., \& Schipke, A. (2011) Bankers on the Beach. Finance and Development, 48(2), 42-45.

Masciandaro, D. (2008). Offshore Financial Centers: the political economy and regulation. 2008. European Journal of Law and Economics. December 2008, 26(3), 307-340.

Hines, J. R. Jr. (2010) Treasure Islands. Journal of Economic Perspectives, 24(4), 103-125. https://doi.org/10.1257/ jep.24.4.103

Tint, P., Paas, O., \& Reinhold, K. (2010). Cost-Effectiveness of Safety Measures in Enterprises. Inzinerine EkonomikaEngineering Economics, 21(5), 485-492.

Radaelli, C. (2009). The Politics of Corporate Taxation in the European Union: Knowledge and International Policy Agendas, London, Routledge.

Rose, A. K., \& Spiegel, M. M. (2007). Offshore Financial Centers: Parasites or Symbionts? Economic Journal, 117(523), 1310-35.

Rixen, T. (2013). Why reregulation after the crisis is feeble: Shadow banking, offshore financial centers, and jurisdictional competition. Regulation \& Governance. 7(4), 435-459. https://doi.org/10.1111/rego.12024

Picard, P. M., \& Pieretti, P. (2011). Bank secrecy, illicit money and offshore financial centers. Journal of Public Economics 95(7/8), August 2011, Pages 942-955.

Taujanskaite, K., Milcius, E., \& Saltenis, S. (2016). Control of Non-Performing Loans in Retail Banking by Raising Financial and Consumer Awareness of Clients. Inzinerine Ekonomika-Engineering Economics, 27(4), p. 405-416. http://dx.doi.org/10.5755/j01.ee.27.4.16511 
Snieska, V., Gaidelys, V., \& Guzavicius, A. (2006). Factors impacting offshore company activities after the EU enlargement. Inzinerine Ekonomika-Engineering Economics, 1(46), p. 38-44.

Snieska, V., \& Sliburyte, L. (1999). Konkurencijos tyrimas ir konkurencingumo valdymo informacinio aprupinimo sistema. Inzinerine Ekonomika-Engineering Economics, 2(17), 43-47.

Stungys, K., Galdikas, K., Venslovas, I., Sakalauskas, A. (2001). Ofsorinis verslas. Vilnius : Kredito brokeris, 2001.

UNCTAD (2015). WIR13 FDI and offshore finance. Geneva. United Nations, p. 17.

UNCTAD (2015). TDR14 for further recommendations specifically regarding EITI. New York. United Nations, p. 194-195.

US Taxes (2012). Bloomberg.com. New York. P. 2012.

Vlcek, W. B. (2006). Small States and the Challenge of Sovereignty: Commonwealth Caribbean Offshore Financial Centers and Tax Competition. Thesis submitted for the degree of Doctor of Philosophy in International Relations The London School of Economics and Political Science University of London.

World Bank (2010). Worldwide Governance Indicators. Retrieved from http://www.govindicators.org

The article has been reviewed.

Received in April, 2014; accepted in December, 2016 